\title{
The Effects of Task Type Planning on Students' Essay Writing: A Study of Iranian EFL Learners
}

\author{
Reza Panahi \\ Shiraz Azad University, Shiraz, Iran
}

\begin{abstract}
This study investigated the effects of planning on second-language written production with regard to proficiency level, and task type. The participants were 157 Iranian learners of English as Foreign Language (EFL) learners attending a four-year university program in Iran. They were asked to complete two different types of writing tasks i.e., expository writing task and argumentative writing task in different planned conditions i.e. Individual Planned Condition and Collaborative Planned Condition over a two-week period. In the Individual Planned Condition, the learners were given $\mathbf{1 0}$ minutes for individual planning in the prestructured task sheet and then were asked to write an essay for 30 minutes. In the Collaborative Planned Condition, learners were allowed to interact with a peer during planning and were required to independently complete an essay. Participants' written products were evaluated on five analytic measures covering the areas of Content, Organization, and Language in Use, Grammar, and Mechanics. The results of MANOVA test indicated that the planned condition had an impact on learners' written performance in both tasks. Individually considered, learners in the Collaborative Planned Condition were able to achieve significantly higher scores in all the analytic features in Task 1 (Expository writing task). In contrast, there were no significant mean differences between two conditions in Task 2 (Argumentative writing task). The results also indicated that proficiency had influenced learners' written performance in both tasks. The proficiency effect was consistently found throughout the analytic scores Task 1 and Task 2 . However, the interaction between condition and proficiency was not found in the two tasks. The results of repeated measures for the effect of task type revealed that significant mean differences were only found in the Mechanics section. It is concluded that Iranian EFL learners' written performance was affected by planned condition and proficiency, but only to a small degree by the nature of task type with regard to the five analytic features.
\end{abstract}

Index Terms - task type planning, essay writing, Iranian learners, EFL, expository writing task, an argumentative writing task

\section{INTRODUCTION}

Since the oral skills have received the most attention in Iran, there is also a need for written communicative skills. For several decades, the traditional form-focused and product oriented instruction has been the dominate method of teaching Iranian students to write in their L2. So as the result, the errors in the surface level have been omitted and the focus has shifted to the final products within an emphasis on accuracy.

According to Bagheri (2007) due to this focus on the final product, Iranian learners have had little opportunity to edit and revise their texts or to interact with peers or on instructor during the completion of writing tasks. Thus, Iranian learners have failed to achieve a high level of $\mathrm{L}_{2}$ writing proficiency party because of these form- focused, product oriented instructional practices.

With the rise of communicative language teaching in Iran since the late 1983, a pedagogical shift from a traditional, product - oriented approach to a process-oriented approach has been motivated to enhance L2 writing abilities in communicative way. Some researchers such as Riazi and Riasati (2011) have proposed that prewriting exercises, multiple drafting cycles, interaction through instructor feedback, or peer review sessions would be beneficial to Iranian learners from the process-oriented perspective.

The present study attempts to find a balance between a learners' writing process and their writing products in the context of task based instruction by focusing on planning and its impact on the language development of Iranian English learners. To do this the key terms are introduced and dealt with in the following sections.

- Task Type Planning: An activity which is designed to help achieve a particular learning goal. (Richards.J.C.2002)

- Essay Writing: in composition a longer piece of writing, particularly one that is written by students as part of course of study or by a writer writing for publication which expresses the writer's viewpoint on a topic. (Richards.J.C.2002)

- Iranian Learners: Those learners who live and study in Iran where the spoken language is Farsi.

- EFL: those learners who learn English in a formal classroom settings, with limited or no opportunities for use outside the classroom, in a country in which English doesn't play an important role in internal communication( Richards \& Schmidt, 2002).

- Expository writing task: According to Roca de Larios et al. (1999), in an expository writing task, participants can use their own experience in a more familiar domain to do the task. 
- Argumentative writing task: An argumentative writing task is expected to be more cognitively demanding because it requires the participants to deal with unfamiliar information and to decide how to support or defend their own position on a given topic.

\section{Theoretical Framework}

As Ortega (1999, p. 113) stated, despite advances in L2 writing research, many fundamental questions still remain unresolved. How planning benefits writing performance is one such vague area that needs to be answered. Numerous planning studies have defined the construct of planning as "the availability of a certain amount of time immediately before performing the experimental tasks" Central to the planning research in the present study is the notion of "planned condition," which refers to any condition that allows for planning. It includes manipulation of time or task conditions as variables.

Since planning plays a role in formulating ideas and generating content and how planning expertise can facilitate $\mathrm{L}_{2}$ task performance, and how different task types affect the planning process, the research findings from both task-based research and L2 writing research can be facilitated to implement a more efficient teaching method with better understanding of learners' individual differences.

\section{Objectives of the Study}

This study investigates how certain aspects of learners' written performance are affected in different planned conditions and to use the results of the analyses to improve learners' L2 writing process in the classroom context. This study was designed to examine the relationships among planned condition, proficiency level, and task type on the five dimensions of linguistic features including Content, Organization, Language in Use, Grammar, and Mechanics.

This study would provide a new knowledge base for the key variables shaping $\mathrm{L}_{2}$ writing task performance: planned conditions, writing task types, and proficiency levels.

\section{Research Questions}

Based on the objectives, this study seeks to answer the following questions;

1. What are the effects of task type on the overall quality of learners' written products?

2. What are the effects of planned conditions on the overall quality of learners' written products?

3. What's the relationship between proficiency and the overall quality of learners' written products?

\section{MethodOLOGY}

\section{Participants}

127 students, who were studied at Islamic Azad University of Shiraz and Shiraz state universities in the winter 2012, were participated in this study. Participants were given two different types of task such as expository texts and argumentative text within the limited time. The participants also had individual interviews after the task completion. All interviews were audio taped and transcribed verbatim. Two M.A. students majoring in EFL evaluated the participants' essays according to the given scoring criteria. The results indicated that there was no global effect of planning on the quality of a written text.

Each participant was notified about the results of the writing tasks with a detailed comment from the two raters. Of the 127 participants, 54 were male and 73 were female. The participants varied from freshman to senior students and their majors were also diverse including English translation, teaching, and literature. Their age ranged from 18 to 25 . At the time of data collection, they had been learning English for an average of 7-11 years including elementary school, junior high, high school, pre-university and university. Three - fourths of the participants stated that they had extracurricular English instruction in a private institution for some years. It indicated that Iranian learners have been mostly exposed to English in a formal instructional setting either in a school or in a private institution as part of extracurricular activity.

\section{INSTRUMENTS}

Instruments used in this study include; pretest materials, writing tasks, task conditions, scoring rubrics used to rate learners' written products, and scoring procedures.

\section{- Pretest material}

To determine participants' $\mathrm{L}_{2}$ proficiency level, the multiple-choice test of Oxford Quick Placement Test was used. This test was selected because it is inexpensive, easy to administer, and easy to score objectively.

The scores of the Oxford Quick Placement Test grammar section were entered by SPSS and then calculated by ANOVA analysis. Table 1 shows the descriptive statistics for Oxford Quick Placement Test "Structure and Written Expression" section scores. The results indicate that learners in the Individual Planned Condition had higher mean scores (25.24) than learners in the Collaborative Planned Condition (24.20). In addition, learners' mean scores in the Individual Planned Condition (7.29) had more variation than those in the Collaborative Planned Condition (6.41).

TABLE 1

DESCRIPTIVE STATISTICS FOR OXFORD QUICK PLACEMENT TEST SECTION SCORES

\begin{tabular}{|l|l|l|l|l|l|}
\hline & $\mathrm{N}$ & Mean & SD & Minimum & Maximum \\
\hline Individual Planned Condition & 58 & 25.24 & 7.29 & 0.0 & 36.0 \\
\hline Collaborative Planned Condition & 69 & 24.20 & 6.41 & 10.0 & 37.0 \\
\hline Grand Total & 127 & 24.68 & 6.81 & 0.0 & 37.0 \\
\hline
\end{tabular}


The results of an ANOVA test presented in Table 2 indicate that there were no statistically significant mean differences between the two conditions in the Oxford Quick Placement Test section scores. Therefore, the ANOVA results for the Oxford Quick Placement Test mean scores suggest that the two groups did not show difference in terms of their general L2 proficiency.

TABLE 2

ONE - WAY MANOVA RESULTS FOR OXFORD QUICK PLACEMENT TEST SECTION SCORES

\begin{tabular}{lllll}
\hline Factor & Sum of squares & Df & Mean square & F \\
\hline Condition & 33.984 & 1 & 33.984 & .729 \\
\hline Error & $5,825.780$ & 125 & 46.606 & \\
\hline
\end{tabular}

\section{Writing Task}

Two writing tasks (Expository and Argumentative) were selected for this study. Within each planned condition, the participants were asked to complete two tasks over a period of two weeks. Both tasks were adapted from the Test of Written English (TWE) sample writing prompts accessible to the public (Educational Testing Service, 2004 - 2005). The TWE is intended to demonstrate test takers' ability to compose an essay in standard written English and it has been carried out as a subsection of Oxford Quick Placement Test battery (ETS, 2004-2005). Since TWE writing task concerns crucial aspects of language used in academic settings, it is acceptable to use it in an EFL educational context like Iran and the test results can be possibly used for academically based decisions, accordingly.

\section{$\checkmark$ Task conditions}

Skehan\& Foster (1999, p.121) reported that a task condition is referred to as 'manipulation of what happens while the task itself is running: In this study, task condition is operationalized by the two types of planned conditions. Two planned conditions include Individual planned condition and collaborative planned condition.

Table 3 show a description of the two conditions in this study.

TABLE 3

DESCRIPTION OF PLANNED CONDITIONS AND COLLABORATIVE PLANNED CONDITION

\begin{tabular}{ll}
\hline Planned condition & Description \\
\hline $\begin{array}{l}\text { Individual Planned Condition: } \\
\text { - It includes a task sheet with pre-structured outline of writing given, } \\
\text { individual planning process, and writing an essay. }\end{array}$ & $\begin{array}{l}\text { Participants are given a structured form for planning and then asked } \\
\text { to write an essay as they had planned it. }\end{array}$ \\
\hline $\begin{array}{l}\text { Collaborative Planned Condition: } \\
\text { - It includes a task sheet with pre-structured outline of writing given, } \\
\text { interaction with a peer, and writing an essay }\end{array}$ & $\begin{array}{l}\text { Participants are allowed to interact with a peer during planning, } \\
\text { while taking notes individually on the task sheet given to them. } \\
\text { Afterward, they independently write an essay as they had planned it } \\
\text { with their partner. }\end{array}$ \\
\hline
\end{tabular}

\section{- Rating Rubrics}

Kroll (1998) mentioned that analytic scoring allows raters to identify different aspects of writing and provides detailed diagnostic information about the learners' writing performance. A modified version of Cohen's (1994) and Jacobs, Zinkgraf, Wormuth, Hartifiel, and Hughey's (1981) scale is used for this study with a focus on five aspects of writing: Content, Organization, Language in use, Grammar, and Mechanics. The Content dimension includes the presence of main ideas, logical development of ideas, and supporting ideas with proper examples. The Organization dimension specifies the proper sequencing of ideas and use of cohesive devices. The Language in Use dimension focuses on the range of vocabulary and the use of proper register. The Grammar dimension refers to grammatical construction in terms of accuracy while the Mechanics dimension focuses on punctuation, spelling, capitalization, and indentation. Analytic scoring is indicated as a band score ranging from 1 to 5. Table 4 details the itemized characteristics of textual features that were evaluated by the raters in analytic scoring.

TABLE 4

LINGUISTIC AND DISCOURSE FEATURES OF ANALYTIC SCORING INSTRUCTIONS

\begin{tabular}{ll}
\hline Linguistic and discourse features & \\
\hline Content & $\begin{array}{l}\text { Logical development of ideas } \\
\text { Main ideas, supporting ideas, and examples }\end{array}$ \\
\hline Organization & $\begin{array}{l}\text { Sequence of introduction, body, and conclusion } \\
\text { Use of cohesive devices }\end{array}$ \\
\hline Language In use & Language in use: choice of vocabulary Register \\
\hline Grammar & Sentence - level structure \\
\hline Mechanics & Punctuation \\
& Spelling, capitalization, indentation \\
\hline
\end{tabular}

\section{Scoring procedure}

Two experienced M.A students, majoring in English Language Teaching, rated all the learners' written products. A rater training session was held by the researcher before the raters began to score the written texts in order to minimize an individual rater's variability and to enhance inter-rater reliability. 
The raters were given a standardized set of instructions that defines the dimensions of the scoring instructions for the study. According to the instructions, raters were required to scan all sets of the essays before assigning a score to any composition. Afterward, they had enough time to assess the essays accurately and fairly in a setting where they felt comfortable. Raters were asked to use full 5- point scales in the analytic scoring process.

The maximum mark given for each section was 5, and the total number of the section is five as follows: Content, Organization, and Language in Use, Grammar, and Mechanics. Thus, the maximum composite score of all the sections was 25 in total. The final score for each written product is the average of the two raters' scores. Where there was unacceptable disagreement of more than one point per subsection, a third rater was invited to resolve a score discrepancy. Final determination of rating was the rating agreed upon by the two raters, or an average of rating, when those ratings represented acceptable disagreement within one point score difference.

\section{Inter-rater Reliability}

The coefficient alpha was used to calculate the Inter-rater reliability between two raters based on 5 Likert scale. Table 5 shows the results.

TABLE 5

RELIABILITY ESTIMATES FOR ANALYTIC SCORES IN TASK 1 AND TASK2

\begin{tabular}{ll}
\hline Task 1 & Reliability Estimates \\
\hline Content & .83 \\
\hline Organization & .83 \\
\hline Language in Use & .76 \\
\hline Grammar & .68 \\
\hline Mechanics & .67 \\
\hline Task 2 & .89 \\
\hline Content & .77 \\
\hline Organization & .64 \\
\hline Language in Use & .50 \\
\hline Mrammar & .56 \\
\hline
\end{tabular}

Overall, reliability estimates in Table 4.1 indicate that the rating of the two raters for the analytic features were more consistent in Task 1 than those in Task 2. Compared to task 1, the reliability estimates among the five analytic scores in Task 2 showed some variation. That is, the ranges of reliability estimates for Task 1 and Task 2 were .67-.83 and .50.89 respectively. For each task, the rating for Content and Organization showed greater consistency between the two raters than for Language in Use, Grammar, and Mechanics. These results suggest that Task 2 as an argumentative writing task was challenging for the raters to discriminate in score judgment rather than Task 1 as an expository writing task in this present study.

\section{Data collection procedures}

All the data were collected over a 3- week period in five L2 English classes. Before the experiment, participants were informed that all details of the procedures would be confidential and their essay was not graded as part of their academic achievement. Then, each participant completed a questionnaire to provide background information regarding previous English language learning experience .Besides, a pretest was administered.

The participants had pressure to perform a task within a specified time limit. the 30 - minute time limit was given to participants to complete the task.

To ensure that the participants actually engaged in planning, they were asked to make written notes on a given task sheet in both task conditions, after task sheet in both task conditions. After task completion, all the writings artifacts that the participants generated during task completion were retrieved. These writings included the planning task sheet and written products.

In the present study, the task was described in both English and Farsi, and actual instruction was provided in Farsi on the grounds that the study is not intended to test participants' comprehension of the second language. The participants were told that they could not use a dictionary or ask for help during task completion. This decision was made because the study was intended to examine how learners handle their tasks solely depending on a given task condition without any external feedback.

\section{Data Analysis Procedure}

To measure the effects of condition (Individual planned condition and collaborative planned condition), and proficiency level (advanced, Intermediate, and Novice) on learners' written products for both tasks, using multivariate analysis of variance (MANOVA) were carried out with the composite scores for two tasks. Thus, a MANOVA test was used to examine mean score differences on two dependent measures. In addition, post hoc tests were used to investigate which pairs of comparisons among the proficiency levels lead to significant results. SPSS version 16.0 was utilized to perform all the statistical analysis.

\section{FINDINGS AND DISCUSSION}


The researcher used two separate sets of MANOVA for both Task 1 and Task 2 in a separate section to investigate the effects of condition (Individual Planned Condition and Collaborative Planned Condition), and proficiency level (Advanced, Intermediate, and Novice) on learners' written products with the set of the five analytic scores. There were 2 kinds of variables: independent variables such as conditions and proficiency levels and the dependent variables like the set of the five analytic scores in Task 1 and Task 2. Thus, a MANOVA design was used to examine mean score differences on the five dependent variables. Later, post hoc tests using the Scheffe method were used to asses which pairs of comparisons among the three proficiency levels led to significant results.

\section{Analysis of Analytic Scores between Group Comparisons: Condition and Proficiency (Task 1)}

The descriptive statistics for the five analytic scores in Task 1 are reported in Table 6. Regardless of the learners' Proficiency, all the analytic scores in the Collaborative Planned Condition were consistently higher than those in the Individual Planned Condition. It is noticeable that Advanced level learners showed relatively higher mean scores in Content (3.98) and Organization (3.78) section in the Collaborative Planned Condition compared to the mean scores of Content (2.70) and Organization (2.57) in the Individual Planned Condition. The mean scores for the Mechanics section in the collaborative Planned Condition are the lowest among these of the other analytic measure across the three proficiency levels (Advanced $=2.91$, Intermediate $=2.46$, and Novice $=2.15$ ), while mean scores for the Grammar section are the lowest in the Individual Planned Condition (Advanced =2.57, Intermediate $=2.18$, and Novice $=1.66$ ). Additionally, mean scores for the Content and Organization section in the Collaborative Planned Condition had higher variation ranging from .72 to 102 compared to those for the Content and Organization section in the Individual Planned Condition ranging from .80 to 95 .

TABLE 6

DESCRIPTIVE STATISTICS FOR ANALYTIC SCORES IN TASK 1

\begin{tabular}{|c|c|c|c|c|c|c|c|}
\hline & $\underbrace{}_{\text {Proficiency }}$ & $\begin{array}{r}\text { Measures } \\
\text { possible) }\end{array}$ & $\begin{array}{l}\text { Content } \\
\text { (5) }\end{array}$ & $\begin{array}{l}\text { Organization } \\
\text { (5) }\end{array}$ & $\begin{array}{l}\text { Language in } \\
\text { Use (5) }\end{array}$ & $\begin{array}{l}\text { Grammar } \\
\text { (5) }\end{array}$ & mechanics \\
\hline 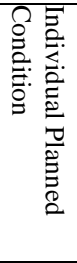 & $\begin{array}{l}\text { Advanced } \\
(n=22) \\
\text { Intermediate } \\
(n=20) \\
\text { Novice } \\
(n=16) \\
\text { Grand Total } \\
(n=58)\end{array}$ & $\begin{array}{l}\text { Mean } \\
\text { SD } \\
\text { Mean } \\
\text { SD } \\
\text { Mean } \\
\text { SD } \\
\text { Mean } \\
\text { SD } \\
\end{array}$ & $\begin{array}{l}2.70 \\
0.80 \\
2.28 \\
0.80 \\
1.94 \\
0.91 \\
2.31 \\
0.84 \\
\end{array}$ & $\begin{array}{l}2.57 \\
0.95 \\
2.03 \\
0.83 \\
2.12 \\
0.81 \\
2.24 \\
0.86 \\
\end{array}$ & $\begin{array}{l}2.55 \\
0.53 \\
2.23 \\
0.64 \\
1.69 \\
0.57 \\
2.16 \\
0.58 \\
\end{array}$ & $\begin{array}{l}2.57 \\
0.66 \\
2.18 \\
0.75 \\
1.66 \\
0.65 \\
2.14 \\
0.69 \\
\end{array}$ & $\begin{array}{l}2.61 \\
0.55 \\
2.35 \\
0.56 \\
1.84 \\
0.68 \\
2.27 \\
0.60 \\
\end{array}$ \\
\hline 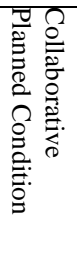 & $\begin{array}{l}\begin{array}{l}\text { Advanced } \\
(\mathrm{n}=23)\end{array} \\
\text { Intermediate } \\
(\mathrm{n}=26) \\
\text { Novice } \\
(\mathrm{n}=20) \\
\text { Grand Total } \\
(\mathrm{n}=69)\end{array}$ & $\begin{array}{l}\text { Mean } \\
\text { SD } \\
\text { Mean } \\
\text { SD } \\
\text { Mean } \\
\text { SD } \\
\text { Mean } \\
\text { SD }\end{array}$ & $\begin{array}{l}3.89 \\
0.80 \\
3.12 \\
1.00 \\
2.35 \\
0.86 \\
3.12 \\
0.89\end{array}$ & $\begin{array}{l}3.78 \\
0.72 \\
3.14 \\
1.02 \\
2.55 \\
0.79 \\
3.16 \\
0.84 \\
\end{array}$ & $\begin{array}{l}3.44 \\
0.68 \\
2.67 \\
0.87 \\
2.33 \\
0.52 \\
2.81 \\
0.69\end{array}$ & $\begin{array}{l}3.02 \\
0.66 \\
2.48 \\
0.67 \\
2.28 \\
0.41 \\
2.59 \\
0.58\end{array}$ & $\begin{array}{l}2.91 \\
0.58 \\
2.46 \\
0.55 \\
2.15 \\
0.33 \\
2.51 \\
0.49\end{array}$ \\
\hline
\end{tabular}

A MANOVA was performed to examine the effects of condition and proficiency on the five dependent variables in Task 1. The MANOVA results are presented in Table 7 the results for the condition effect are Wilk's $\mathrm{A}=.734, \mathrm{~F}_{5,117}=$ $8.474, \mathrm{P}<.000$. The researcher found that the set of five analytic scores can be affected by condition factors. In other words, the set of the five analytic scores in Task 1 vary between individual Planned Condition and Collaborative Planned Condition. The significant condition effect shows that learners in the Collaborative Planned Condition performed differently from the learners in the Individual Planned Condition in all the analytic features (Content, Organization, and Language in Use, Grammar, and Mechanics).

The proficiency effect was found to be significant, Wilk's $A=.662, \mathrm{~F}_{10,234}=5.356, \mathrm{P}<.000$ on the set of the five analytic measures. Like the result of the condition effect, the proficiency factor also had an impact on learners' written performance in all the analytic features. Specifically, these results indicate that Advanced level learners performed differently from Intermediate level learners or Novice level learners regarding the five analytic scores. However, it was found that the multivariate interaction of condition and proficiency was not statistically significant.

TABLE7

RESUlts OF MUltivariate TESTS FOR ANALYTIC SCORES IN TASK 1

\begin{tabular}{|c|c|c|c|c|c|}
\hline Factor & Wilks' A Value & $\mathrm{F}$ & Hypothesis $d f$ & Error $d f$ & P Value \\
\hline Condition & $.734 *$ & 8.474 & 5 & 117 & .000 \\
\hline Proficiency & $.662 *$ & 5.356 & 10 & 234 & .000 \\
\hline $\mathrm{X}$ & .869 & 1.706 & 10 & 234 & .080 \\
\hline Proficiency & & & & & \\
\hline
\end{tabular}

The results of the follow - up univariate ANOVAs presented in Table 8 indicate that significant condition effects were found in all the analytic categories of Content $\left(\mathrm{F}_{1,126}=27.244, \mathrm{P}<.000\right)$, Organization $\left(\mathrm{F}_{1,126}=34.558, \mathrm{P}<.000\right)$, Language in Use $\left(\mathrm{F}_{1,126}=30.779, \mathrm{P}<.000\right)$, Grammar $\left(\mathrm{F}_{1,126}=15.740, \mathrm{P}<.000\right)$ and Mechanics $\left(\mathrm{F}_{1,126}=5.929 \mathrm{P}<.016\right)$, 
respectively. The results suggest that learners in the Collaborative Planned Condition scored higher than learners in the Individual Planned Condition in all the five analytic features in Task1. In other words, learners benefited from collaborative planning to carry out the given expository writing task in this present study.

Regarding the effects of proficiency, the results show that there were significant proficiency effects in all the analytic categories of content $\left(\mathrm{F}_{2,125}=17.718, \mathrm{P}<.000\right)$, Organization $\left(\mathrm{F}_{2,125}=10.218, \mathrm{P}<.000\right)$, Language in Use $\left(\mathrm{F}_{2,125}=22.365\right.$, $\mathrm{P}<.000)$, Grammar $\left(\mathrm{F}_{2,125}=16.762, \mathrm{p}<.000\right)$, and Mechanics $\left(\mathrm{F}_{2,125}=19.508, \mathrm{p}<.000\right)$, respectively. These results indicate that learners performed differently across the three proficiency levels. Advanced level learners obtained the highest scores in all the analytic features in comparison to those of the Intermediate and Novice level learners. Intermediate level learners obtained higher mean scores than those of Novice level learners. No between - group interaction effect between condition and proficiency was found to be significant in Task 1.

TABLE 8

RESULTS OF ANOVA TESTS FOR ANALYTIC SCORES IN TASK1

\begin{tabular}{|c|c|c|c|c|c|c|}
\hline Factor & $\begin{array}{l}\text { Analytic } \\
\text { Measures }\end{array}$ & Sum of squares & $d f$ & $\begin{array}{l}\text { Mean } \\
\text { Square }\end{array}$ & $\mathrm{F}$ & $P$ Value \\
\hline \multirow[t]{5}{*}{ Condition } & Content & 20.531 & 1 & 20.531 & $27.244^{*}$ & .000 \\
\hline & Organization & 26.069 & 1 & 26.069 & $34.558 *$ & .000 \\
\hline & Language in Use & 13.454 & 1 & 13.454 & $30.779 *$ & .000 \\
\hline & Grammar & 6.551 & 1 & 6.551 & $15.740 *$ & .000 \\
\hline & Mechanics & 1.774 & 1 & 1.774 & $5.929 *$ & .016 \\
\hline \multirow[t]{6}{*}{ Proficiency } & Content & 26.704 & 2 & 13.352 & $17.718^{*}$ & .000 \\
\hline & Organization & 15.416 & 2 & 7.708 & $10.218^{*}$ & .000 \\
\hline & Language in Use & 19.552 & 2 & 9.776 & $22.365^{*}$ & .000 \\
\hline & Grammar & 13.953 & 2 & 6.977 & $16.762 *$ & .000 \\
\hline & Mechanics & 11.676 & 2 & 5.838 & $19.508 *$ & .000 \\
\hline & Content & 2.976 & 2 & 1.488 & 1.975 & .143 \\
\hline \multirow{4}{*}{$\begin{array}{l}\text { Condition } \\
\text { X } \\
\text { Proficiency }\end{array}$} & Organization & 3.524 & 2 & 1.762 & 2.336 & .101 \\
\hline & Language in Use & 1.104 & 2 & .552 & 1.262 & .287 \\
\hline & Grammar & .488 & 2 & .244 & .586 & .558 \\
\hline & Mechanics & .264 & 2 & .132 & .441 & .644 \\
\hline
\end{tabular}

The results of the Scheffe post hoc analyses are presented in Table 9 These results show that there was a considerable mean difference among the pair wise comparisons within the three proficiency levels. Distinctively, all the comparison groups showed significant differences except two pair wise comparisons which include the comparison between Intermediate and Novice level groups in Organization and Grammar section.

TABLE 9

POST HOC SCHEFFE RESULTS FOR PROFICIENCY IN TASK 1

\begin{tabular}{|c|c|c|c|c|}
\hline Analytic & $\begin{array}{l}\text { Pair wise Comparison } \\
\text { for proficiency }\end{array}$ & Mean Difference & $\mathrm{SE}$ & P Value \\
\hline \multirow{4}{*}{ Content } & Advanced - Intermediate & $.56^{*}$ & .18 & .010 \\
\hline & Advanced - Novice & $1.14^{*}$ & .19 & .000 \\
\hline & Intermediate - Novice & $.58 *$ & .19 & .012 \\
\hline & Advanced - Intermediate & $.54 *$ & 18 & .015 \\
\hline \multirow[t]{2}{*}{ Organization } & Advanced - Novice & $.83 *$ & .19 & .000 \\
\hline & Intermediate - Novice & .29 & .19 & .325 \\
\hline Language & Advanced - Intermediate & $.52 *$ & .14 & .001 \\
\hline \multirow[t]{3}{*}{ in Use } & Advanced - Novice & $.96^{*}$ & .15 & .001 \\
\hline & Intermediate - Novice & $.44 *$ & .15 & .014 \\
\hline & Advanced - Intermediate & $.45^{*}$ & .14 & .005 \\
\hline \multirow[t]{3}{*}{ Grammar } & Advanced - Novice & $.80 *$ & .14 & .000 \\
\hline & Intermediate - Novice & .35 & .14 & .057 \\
\hline & Advanced - Intermediate & $.35^{*}$ & .11 & .010 \\
\hline \multirow[t]{2}{*}{ Mechanics } & Advanced - Novice & $.75^{*}$ & .12 & .000 \\
\hline & Intermediate - Novice & $.40 *$ & .12 & .006 \\
\hline
\end{tabular}

\section{Analysis of Analytic Scores between Group Comparisons: Condition and Proficiency (Task 2)}

Table 10presents a summary of the descriptive statistics for the analytic measures in Task2. Overall, five analytic mean scores of Advanced and Intermediate level learners in the Collaborative Planned Condition were consistently higher than those of Advanced and Intermediate level learners in the Individual Planned Condition. In contrast, the mean scores of Novice level learners in the Individual Planned Condition were higher than those of Novice level learners in the Collaborative Planned Condition in all the analytic features.

In particular, in the Content (3.59) section of Collaborative Planned Condition, Advanced level learners obtained higher mean scores than the Individual Planned Condition. In the Organization (2.75) section of Individual Planned Condition, Novice level learners obtained relatively higher mean scores than the Collaborative Planned Condition. 
Overall, the mean score differences between two conditions were not noticeable compared to the result of the descriptive statistics in Task 1.

TABLE 10

DESCRIPTIVE STATISTICS FOR ANALYTIC SCORES IN TASK 2

\begin{tabular}{|c|c|c|c|c|c|c|c|}
\hline & Proficiency & $\begin{array}{r}\text { Measures } \\
\text { al possible) }\end{array}$ & $\begin{array}{l}\text { Content } \\
(5)\end{array}$ & $\begin{array}{l}\text { Organization } \\
(5)\end{array}$ & $\begin{array}{l}\text { Language in } \\
\text { Use } \\
(5)\end{array}$ & $\begin{array}{l}\text { Grammar } \\
(5)\end{array}$ & $\begin{array}{l}\text { Mechanics } \\
(5)\end{array}$ \\
\hline \multirow{8}{*}{ 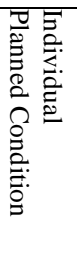 } & \multirow{8}{*}{$\begin{array}{l}\begin{array}{l}\text { Advanced } \\
(n=22)\end{array} \\
\text { Intermediate } \\
(n=20) \\
\text { Novice } \\
(n=16) \\
\text { Grand Total } \\
(n=58)\end{array}$} & Mean & 3.23 & 3.23 & 2.98 & 2.68 & 2.91 \\
\hline & & SD & 0.98 & 0.96 & 0.82 & 0.59 & 0.71 \\
\hline & & Mean & 2.45 & 2.60 & 2.22 & 2.13 & 2.40 \\
\hline & & $\mathrm{SD}$ & 0.86 & 0.93 & 0.57 & 0.28 & 0.53 \\
\hline & & Mean & 2.53 & 2.75 & 2.09 & 2.06 & 2.22 \\
\hline & & SD & 0.83 & 0.75 & 0.38 & 0.25 & 0.45 \\
\hline & & Mean & 2.74 & 2.86 & 2.43 & 2.29 & 2.51 \\
\hline & & SD & 0.89 & 0.88 & 1.77 & 0.37 & 0.56 \\
\hline \multirow{8}{*}{ 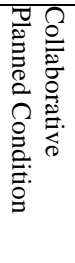 } & \multirow{8}{*}{$\begin{array}{l}\text { Advanced } \\
(n=23) \\
\text { Intermediate } \\
(n=26) \\
\text { Novice } \\
(n=20) \\
\text { Grand Total } \\
(n=69)\end{array}$} & Mean & 3.59 & 3.33 & 2.85 & 2.76 & 2.98 \\
\hline & & SD & 1.03 & 0.94 & 0.51 & 0.50 & 0.59 \\
\hline & & Mean & 2.73 & 2.83 & 2.25 & 2.25 & 2.85 \\
\hline & & SD & 0.90 & 0.76 & 0.53 & 0.55 & 0.61 \\
\hline & & Mean & 2.40 & 2.43 & 1.93 & 2.00 & 2.30 \\
\hline & & SD & 0.90 & 0.92 & 0.52 & 0.46 & 0.47 \\
\hline & & Mean & 2.91 & 2.86 & 2.43 & 2.43 & 2.71 \\
\hline & & SD & 0.94 & 0.87 & 0.50 & 0.50 & 0.56 \\
\hline
\end{tabular}

A MANOVA was performed to investigate the effects of condition and proficiency on the five dependent variables in Task 2. the MANOVA results are presented in Table11. The results for the condition effect, Wilk's $\mathrm{A}=.867, \mathrm{~F}_{5,117}=$ $3.583, \mathrm{P}<.005$, indicate that condition factor in Task 2 had impact on learners' written performance with regard to the five analytic scores. It is shown that the set of the five analytic scores in Task 2 varies between the two conditions (Individual Planned Condition and Collaborative Planned Condition). This condition effect suggests that learners in the Collaborative Planned Condition performed differently from the learners in the Individual Planned Condition in all the analytic features (Content, Organization, Language in Use, Grammar, and Mechanics).

The proficiency effect was significant, Wilk's $A=.616, \mathrm{~F}_{10,234}=6.413, \mathrm{P}<.000$ on the set of the five dependent measures. The results suggest that the proficiency factor also influenced learners' written performance across all the analytic features in Task2. These results suggest that the five analytic scores in Task 2 were significantly different for learners with different proficiency levels. However, multivariate interaction of condition and proficiency was not found to be significant in Task2.

TABLE 11

RESUltS OF MULTIVARIATE TESTS FOR ANALYTIC SCORES IN TASK2

\begin{tabular}{l|l|l|l|l|l}
\hline Factor & Wilks' A Value & F & Hypothesis $d f$ & Error $d f$ \\
\hline Condition &. $.867^{*}$ & 3.583 & 5 & 117 & P Value \\
Proficiency X & $.616^{*}$ & 6.413 & 10 & 234 & .005 \\
Proficiency & .939 & .753 & 10 & 234 & .000 \\
& & $*$ P $<.05$ & .674
\end{tabular}

The results of the follow - up univatiate ANOVAs presented in Table 12 indicate that significant condition effects were not found in all the five analytic features in Task 2 unlike the results of Task1.

Meanwhile, the individual results for the proficiency effect were found to be significant. That is, significant differences were detected for the three proficiency levels in all the analytic measures in Task 2, Content $\left(F_{2,125}=13.4\right.$, $\mathrm{P}<.000)$, Organization $\left(\mathrm{F}_{2,125}=7.31, \mathrm{P}<.001\right)$, Language in Use $\left(\mathrm{F}_{2,125}=27.46, \mathrm{P}<.000\right)$, Grammar $\left(\mathrm{F}_{2,125}=24.87\right.$, $\mathrm{P}<.000)$, Mechanics $\left(\mathrm{F}_{2,125}=13.93, \mathrm{P}<.000\right)$, respectively.

The results suggest that learners performed differently across the three proficiency levels. In other words, Advanced level learners scored higher in all the five analytic features than did intermediate level learners while Intermediate level scored higher in all the five analytic features than Novice level learners did. These results are basically the same as the results of Task 1 regarding the proficiency effect. There was, however, no significant interaction between condition and proficiency. 
TABLE 12

RESULTS OF ANOVA TESTS FOR ANALYTIC SCORES IN TASK 2

\begin{tabular}{|c|c|c|c|c|c|c|}
\hline Factor & Analytic Measures & Sum of squares & $d f$ & Mean Square & $\mathrm{F}$ & $P$ Value \\
\hline \multirow[t]{5}{*}{ Condition } & Content & .89 & 1 & .89 & 1.05 & .308 \\
\hline & Organization & .00 & 1 & .00 & 0 & .999 \\
\hline & Language in Use & .26 & 1 & .26 & .77 & .383 \\
\hline & Grammar & .07 & 1 & .07 & .31 & .577 \\
\hline & Mechanics & 1.23 & 1 & 1.23 & 3.68 & .058 \\
\hline \multirow[t]{5}{*}{ Proficiency } & Content & 22.26 & 2 & 11.13 & $13.04 *$ & .000 \\
\hline & Organization & 11.37 & 2 & 5.69 & $7.31 *$ & .001 \\
\hline & Language in Use & 18.41 & 2 & 9.21 & $27.46^{*}$ & .000 \\
\hline & Grammar & 10.98 & 2 & 5.49 & $24.87 *$ & .000 \\
\hline & Mechanics & 9.31 & 2 & 4.65 & 13.93 & .000 \\
\hline \multirow{5}{*}{$\begin{array}{l}\text { Condition } \\
\text { X } \\
\text { Proficiency }\end{array}$} & Content & 1.33 & 2 & .67 & .78 & .46 \\
\hline & Organization & 1.61 & 2 & .81 & 1.04 & .36 \\
\hline & Language in Use & .22 & 2 & .11 & .33 & .72 \\
\hline & Grammar & .19 & 2 & .09 & .42 & .66 \\
\hline & Mechanics & 1.00 & 2 & .50 & 1.50 & .23 \\
\hline
\end{tabular}

The Scheffe post hoc analyses for the proficiency effect in Task 2 are presented in Table 13. The post hoc analyses found that there were significant mean differences among the pair wise comparisons with the three proficiency levels, especially between Advanced and Intermediate level learners, and between Advanced and Novice level learners. Regarding five analytic scores, research just showed differences between Advanced and Intermediate level learners, and also Advanced and Novice level learners in the four areas of Content, Organization, Language in Use, and Grammar section but not in Mechanics section.

TABLE 13

POST HOC SCHEFFE RESULTS FOR PROFICIENCY IN TASK 2

\begin{tabular}{|c|c|c|c|c|}
\hline Analytic & $\begin{array}{l}\text { Pair wise Comparison } \\
\text { for proficiency }\end{array}$ & Mean Difference & SE & P Value \\
\hline \multirow{3}{*}{ Content } & Advanced - Intermediate & $.80^{*}$ & .19 & .000 \\
\hline & Advanced - Novice & $.95^{*}$ & .21 & .000 \\
\hline & Intermediate - Novice & .15 & .21 & .766 \\
\hline \multirow{3}{*}{ Organization } & Advanced - Intermediate & $.55^{*}$ & .18 & .014 \\
\hline & Advanced - Novice & $.71 *$ & .20 & .002 \\
\hline & Intermediate - Novice & .16 & .20 & .721 \\
\hline \multirow{3}{*}{$\begin{array}{l}\text { Language } \\
\text { in Use }\end{array}$} & Advanced - Intermediate & $.67 *$ & .12 & .000 \\
\hline & Advanced - Novice & $.91 *$ & .13 & .000 \\
\hline & Intermediate - Novice & .24 & .13 & .183 \\
\hline \multirow{3}{*}{ Grammar } & Advanced - Intermediate & $.53 *$ & .10 & .000 \\
\hline & Advanced - Novice & $.69 *$ & .11 & .000 \\
\hline & Intermediate - Novice & .17 & .10 & .279 \\
\hline \multirow{3}{*}{ Mechanics } & Advanced - Intermediate & 29 & .12 & .058 \\
\hline & Advanced - Novice & $.68 *$ & .13 & .000 \\
\hline & Intermediate - Novice & $.39 *$ & .13 & .012 \\
\hline
\end{tabular}

\section{Within Group Comparison: Task type}

In this research, five sets of repeated measures study were conducted with the analytic scores in Task 1 and Task 2 to evaluate any differences in learners' written performance. For each analysis, the two task types were repeated measures.

The descriptive statistics for the analytic scores in the two tasks are reported in Table14. The descriptive analysis revealed different results in Task1 and Task2.Overall, the results of the descriptive analysis show that learners had the highest mean score in the Content (2.78) section and the lowest mean score in the Grammar (2.41) section in Task 1. Meanwhile, they achieved the highest score in the Organization (2.88) section and the lowest score in the Grammar (2.33) section in Task 2.

TABLE 14

DESCRIPTIVE STATISTICS FOR ANALYTIC MEASURES IN TASK 1 AND TASK 2

\begin{tabular}{|c|c|c|c|c|c|c|}
\hline & Analytic Measures (Total Possible) & $\mathrm{N}$ & Mean & SD & Min & Max \\
\hline \multirow{5}{*}{ Task 1} & Content (5) & 127 & 2.78 & 1.06 & 1.00 & 5.00 \\
\hline & Organization (5) & 127 & 2.76 & 1.04 & 1.00 & 5.00 \\
\hline & Language in Use (5) & 127 & 2.54 & .83 & 1.00 & 5.00 \\
\hline & Grammar (5) & 127 & 2.41 & .75 & 1.00 & 4.50 \\
\hline & Mechanics (5) & 127 & 2.43 & .63 & 1.00 & 4.00 \\
\hline \multirow{5}{*}{ Task 2} & Content (5) & 127 & 2.85 & 1.00 & 1.00 & 5.00 \\
\hline & Organization (5) & 127 & 2.88 & 0.92 & 1.00 & 5.00 \\
\hline & Language in Use(5) & 127 & 2.41 & 69 & 1.00 & 5.00 \\
\hline & Grammar (5) & 127 & 2.33 & .55 & 1.00 & 3.50 \\
\hline & Mechanics (5) & 127 & 2.65 & .64 & 1.00 & 4.50 \\
\hline
\end{tabular}


Based on the results of the analysis presented above, it can be concluded that the task type didn't influence the learners' written performance except in Mechanics section. In other words, Task 2(Argumentative writing task) only led learners to focus more on the Mechanics section over other analytic features compared to Task 1(Expository writing task).

The repeated measures analysis results in Table 15 indicate that only the mean scores in Mechanics section $\left(F_{1,126}=\right.$ 12.480, $\mathrm{P}<.001$ ) were found to be significant among other analytic features. Similar to the results of the composite scores, these results suggest that task type did not influence the Iranian EFL learners' written performance except in one section, Mechanics.

TABLE 15

REPEATED MEASURES RESULTS FOR ANALYTIC SCORES IN TASK 1 AND TASK 2

\begin{tabular}{|c|c|c|c|c|c|}
\hline Factor & Sum of Squares & $\mathrm{df}$ & Mean Square & $\mathrm{F}$ & P Value \\
\hline Content & .284 & 1 & .284 & .515 & .474 \\
\hline Organization & .886 & 1 & .886 & 1.921 & .168 \\
\hline Language in Use & 1.072 & 1 & .355 & 1.612 & .207 \\
\hline Grammar & .355 & 1 & .355 & 1.612 & .207 \\
\hline Mechanics & 3.087 & 1 & 3.087 & $12.480 *$ & .001 \\
\hline
\end{tabular}

\section{CONCLUSION}

Based on the procedure of the research, condition had an impact on learners' written performance in both tasks regarding the composite scores and the set of the analytic scores. Individually considered, learners in the Collaborative Planned Condition were able to achieve significantly higher composite scores and analytic scores including Content, Organization, Language in Use, Grammar, and Mechanics section in Task 1 (Expository writing task).

In contrast, there were no significant mean differences between two conditions in Task 2 .Therefore, it is feasible to interpret that learners' written performance was not affected by any of the planned conditions in Task 2 (Argumentative writing task).

The results relating to proficiency show that proficiency had substantial influence on learners' written performance in both tasks. The proficiency effect was consistent throughout the analytic scores in Task 1 and Task 2 . However, the interaction between condition and proficiency factors did not influence the written performance as reflected by the five analytic scores in both tasks.

For task type effects on the analytic scores of learners' written performance, significant mean differences were only detected in the Mechanics section.

\section{Pedagogical implication of the study}

The findings of this study help broaden the understanding of second language learners' cognitive writing process involving planning. In addition, the results have pedagogical implications as well as theoretical implications in second language writing and relevance to second language writing assessment.

The results of the conditional effects indicate that the planned conditions had an impact on learners' written performance in both tasks. Thus, these results tend to support the claim that the planning process eased the processing load during task completion and enabled learners to produce a high quality text regardless of condition types.

Specifically, the Collaborative Planned Condition has a positive effect in the expository writing task. Collaboration with a peer was more effective in the expository writing task rather than in the argumentative writing task due to learners' better opportunity to brainstorm their ideas and to build up more reasonable explanations to fulfill the expository writing task through the interaction with a partner. The effects of planning would be greater in a task which has an inherently complex structure or requires learners to produce more difficult linguistic aspects.

In summary, the results of the study confirmed that planning in the L2 writing process enabled learners to lower their cognitive load during task completion and to yield a high quality text with regard to the composite scores and the set of the analytic scores.

Remarkably, collaboration with a partner in the planning process was more effective in generating specific examples and details to help learners develop their own ideas in Task1 (Expository writing task), In the meantime, learners did not benefit from any of the planned conditions to take their own position on a topic and to generate supporting ideas and details in Task 2. As a result, the conclusion drawn here is that the Collaborative Planned Condition was more effective for Iranian EFL learners to complete the Expository writing task than was the Individual Planned Condition.

Based on the learners' knowledge and ability concerning different analytic aspects of written language, and the cognitive demands of the task at hand, the effects of proficiency vary. Advanced level learners did not seem to demonstrate any distinctive pattern with regard to the two tasks. Conversely, the mean scores of Intermediate level learners demonstrated noticeable patterns between the two tasks.

In task2, the mean scores of the Intermediate level learners are similar to the mean scores of the Novice level learners. Learners in both proficiency levels obtained the highest score in Organization section and the lowest score in the Grammar section. In short, the mean scores in Intermediate level learners displayed a different pattern depending on the task types: in Task 1, their score patterns are similar to the score patterns of Advanced level learners while, in Task 2 , 
the score patterns are closer to those of Novice level learners. It seems obvious that Novice level learners benefited from the planned condition itself regardless of the condition types among the three proficiency levels.

In sum, Iranian EFL learners in this study appeared to use the planned conditions to achieve Content or Organization over Grammar from the concept of limited information processing capacity. Indeed, each proficiency level demonstrated their own priority over others in each task. For Novice level learners, the planned conditions played a more active role to fill their limited linguistic resources. The more able learners who can provide less capable learners with the appropriate level of assistance through social interaction help novice level learners move from their current level toward their potential level of development.

In this study, however, Novice level learners greatly improved their writing ability in terms of content, and organization section by utilizing the planned conditions and the task sheet. Consequently, the patterns commonly found in higher proficiency level learners are also shown in the lower proficiency level learners. It is reasoned that the function of the planned condition seems to help even lower proficiency level learners pay more attention to such higher writing processes as content and organization. Thus, it is also possible to conclude that the planned conditions were substantially effective in enhancing less proficient writers' ability to write in this particular study. Each set of analytic scores in Task 1 and Task 2 displayed a distinctive pattern reflecting L2 learners' proficiency level. Among the three proficiency levels, Intermediate level learners showed a somewhat different pattern from others in a sense that their analytic scoring patterns varied depending on the task types, unlike those of Advanced or Novice level learners.

Concerning the characteristics of the proficiency level learners, Iranian L2 learners paid more attention to higher writing processes including content or organization rather than lower writing processes such as morpho-syntactic features such as grammar or mechanics.

The results suggest that the planning process during task completion appears to promote an active engagement of learners to a given task, awareness of positive input, and facilitation of the writing process. Collaborative writing enabled students to discover ideas together and exposed them to different views.

With regard to the task types used in this study, genre-based instruction can be also considered productive in Iranian EFL educational context: instructors provide learners with inaccessible cultural knowledge in their instructional practice while learners are not fully exposed to L2 input and interaction with native speakers. In the EFL Iranian educational context, genre-based instruction can be also an effective approach to enhance learners' writing ability. Eventually, Cumming \&Riazi (2000, p. 68) resulted that L2 writing is viewed as "complex configurations of background and process variables that interrelated students previous educational experiences and present practices learning to write". Thus, it is crucial for writing instructors to keep in mind that the knowledge and skills that make a learner a better writer can be somehow learned or taught through the introduction of a variety of awareness-raising activities and the use of strategies during writing task completion in the classroom context. Moreover, tasks need to be selected based on learners' accessibility and familiarity connected to a real-world situation. There is no one-size-fits-all writing process for L2 learners. Hence, learners need to practice writing in a variety of situations in which learners are involved in producing texts with an opportunity to reflect on the writing process including planning (Johns, 1997).

\section{REFERENCES}

[1] Bagheri, M.S. (2007). Crack. IELTS in a Flash. (Writing task 2). Tehran, Azaran.

[2] Cohen, A. D. (1994). Assessing language ability in the classroom. (2nd ed.). Boston, MA: Heinle and Heinle.

[3] Cumming, A. \&Riazi, A. (2000). Building models of adult second - language writing instruction. Learning and Instruction, 10, 55-71.

[4] Dellerman, P., Coirier, P., \&Marchand, E. (1996). Planning and expertise in argumentative composition. In G. Rijlaarsdam, H. v. d. Bergh, \& M. Couzijn (Eds.), Theories, models and methodology in writing research (pp. 182-195). Amsterdam: Amsterdam University Press.

[5] Jacobs, H. L., Zinkgraf, S. A., Wormuth, D. R., Hartfiel, V. F., \&Hughey, J. B. (1981). Testing ESL composition: A practical approach. Rowley, MA: Newbury House.

[6] Johns, A. M. (1997). Text, role, and context: Developing academic literacies. New York: Cambridge University Press.

[7] Jones, S., \& Tetroe, J. (1987).Composing in a second language. In A. Matsuhashi (Ed.), Writing in real time (pp. 34-57). Norwood, NJ: Ablex.

[8] Knoll, B. (1998). Assessing writing abilities. Annual Review of Applied Linguistics, 18,219-240.

[9] Riazi \& Riasati. (2011). language learning style preferences: A students case study of shiraz EFL Institutes. Asian EFL Journal, 9, 97-125.

[10] Richard.J.C. (2002). Dictionary of Language and Applied Linguistics. Pearson Education Limited. United Kingdom: England.

[11] Roca de Larios, J. R., Murphy, L., \&Manchon, R. (1999). The use of restructuring strategies in EFL writing: A study of Spanish learners of English as a foreign language. Journal of Second Language Writing, 8, 13-44.

[12] Ortega, L. (1999). Planning and focus on form in L2 oral performance. Studies in Foreign Language Acquisition, 21, 109-148.

[13] Skehan, P., \& Foster, P. (1999). The influence of task structure and processing conditions on narrative retellings. Language Learning, 49, 93-120. 
Reza Panahi got M.A. in TEFEL (Teaching English as a Foreign Language) in Shiraz Azad University, Fars, Iran in October 2012. He was born in Shiraz.

He teaches English more than 10 years in the ILI (Iran Language Institute). And he has done his military service.

Mr. Panahi has not been the member of any professional societies. 